75 巻 757 号 (2009-9)

\title{
ナノ振動型レーザトラップにおける プローブ周囲流体解析シミュレータの構築*
}

\author{
田 中 晋 平*1, 高 谷裕 浩*2, 林 照 剛*2
}

\author{
Building an Ambient Fluid Analysis \\ around nm Oscillated Laser Trapping Probe
}

\author{
Shimpei TANAKA*3, Yasuhiro TAKAYA and Terutake HAYASHI \\ ${ }^{* 3}$ Department of Mechanical Engineering, Osaka University, \\ 2-1 Yamada-oka, Suita-shi, Osaka, 565-0871 Japan
}

\begin{abstract}
In order to measure the 3D shape of microcomponents, a novel nano-CMM system has been developed based on an oscillated probing technique, which uses an optically trapped particle. The trapped particle is laterally oscillated at the focal plane of the objective. The frequency response of the oscillated particle typically agrees with the spring-mass-damper model. However the response disagrees with the theoretical curve of the conventional model equation in the range of high frequency. It is considered the difference between experiments and the model equation is caused from the numerical error for the fluid effect, which is applied on condition of creeping flow past a sphere. In this report, we construct a fluid simulation using SMAC method that calculates fluid resistance against an oscillating sphere in noninertial frame of reference. The fluid resistance damp the motion of an oscillating sphere pulled toward focal spot and spring-mass-damper system can be processed with the use of simulation.
\end{abstract}

Key Words : Fluid Resistance, Laser Trapping, SMAC Method, Noninertial Frame of Reference

\section{1. 粕}

レーザトラップとは光放射圧を利用して $\mu \mathrm{m}$ オーダ の微小な物体をレーザで捕捉・操作する技術である. 筆者らは，この技術を応用し，レーザトラップされた 微粒子をセンシングプローブとする光放射圧プローブ 式ナノ $\mathrm{CMM}$ を開発している. 光放射圧プローブ式ナ ノ CMM では，試料表面近傍で励振されるプローブ振 動特性の変化を検出することで座標計測が行われ，大 気中で $\mathrm{nm}$ オーダでの計測を行う ${ }^{(1)}$. プローブをさら に高度化するには振動するプローブまわりの流体解析 が不可欠であり，レーザトラップされた微粒子の周囲 流体による計測の不確かさ評価を行うことで, 計測の 信頼性を向上させることができる，本報では，振動型 レ一ザトラッピングプローブに SMAC 法を用いた流 体解析シミュレー夕を適用し，実験環境でのパラメー タを用いてプローブ球挙動解析をした結果について述 ベる.

\footnotetext{
* 原稿受付 2009 年 3 月 3 日.

*1 学生員, 大阪大学 (ङ 565-0871 吹田市山田丘 2-1).

*2 正員, 大阪大学大学院工学研究科機械工学専攻.

E-mail : takaya@mech.eng.osaka-u.ac.jp
}

\section{2. 微粒子振钦モデル}

強制振動型レーザトラップでは図 1 のようにプロー ブ球を振動させ，周波数解析することでノイズの分離 をはかっている(2). プローブ球の運動モデルを考える と, 振動状態にあるプローブ球は光放射圧によるバネ の作用および周囲流体の粘性によるダンパの作用によ って次式のバネーダンパ系の運動方程式にモデル化す ることができる.

$$
m \ddot{x}+D \dot{x}+k(x-A \sin 2 \pi f t)=F(t)
$$

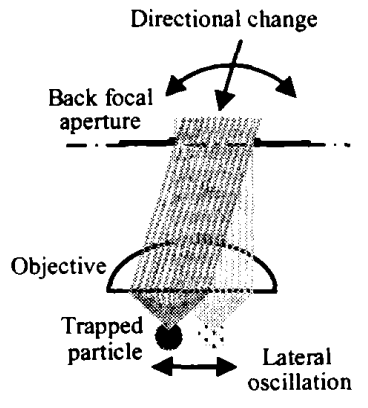

Fig.1 Schematic of lateral oscillation of probe

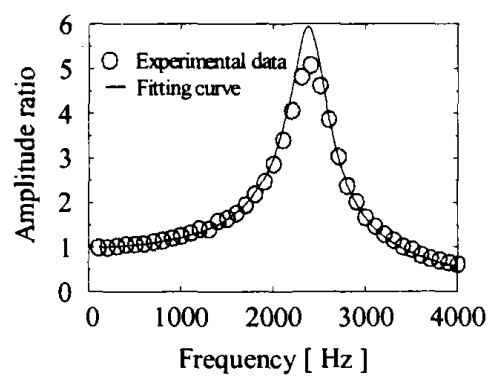

Fig. 2 Frequency response (Amplitude ratio) 
ここで $m$ は捕捉した微粒子の質量, $x$ は微粒子·の振動 方向の位置, $D$ は周囲流体の粘性抵抗係数, $k$ は振動 方向に対するバネ定数，A はビームスポットの励振振 幅, $f$ は励振周波数, $F(t)$ は周囲流体から受けるラン ダム力である．流体中において低速で運動する球体に 対して用いられるストークスの法則が適用できると仮 定すると，周囲流体の粘性抵抗係数には次式で表され るストークスの抵抗係数が用いられる.

$$
D=6 \pi \mu r
$$

ここで $r$ は微粒了·の半径, $\mu$ は周囲流体の粘度を表す。 周囲流体のランダム力に対して正弦波変位励振を与え るとき， $F(t)$ による微粒子の位置変化は無視すること ができる．定常振動の解を

$$
x=X \exp \{i(2 \pi f t)-\varphi\}
$$

と仮定すると, 振幅 $X$ と位相遅れ $\varphi$ は共振周波数 $f_{n}$ を 用いて次のように表される.

$$
\begin{aligned}
& X=\frac{f_{n}^{2}}{\sqrt{\left(f_{n}^{2}-f^{2}\right)^{2}+(D f / 2 \pi m)^{2}}} A \\
& \varphi=\cos ^{-1} \frac{f_{n}^{2}-f^{2}}{\sqrt{\left(f_{n}^{2}-f^{2}\right)^{2}+(D f / 2 \pi m)^{2}}} \\
& f_{n}=\frac{1}{2 \pi} \sqrt{\frac{k}{m}}
\end{aligned}
$$

以上のモデル化により, 実験結果とのフィッティン グを行うと図 2 のようになり，共振周波数近傍におい てモデル式と十分一致しておらず，より適切なフィッ ティングが可能であると考えられる．モデル式から考 えた場合, 誤差の要因としては質量 $m$, 粘性抵抗倸数 $D$, バネ定数 $k$ の 3 つが考えられる. 物体が流体内を 加速度運動するとき, 見かけ上物体の質量が増加し, その影響は付加質量というもので表される．レーザト ラップではプローブ球の密度に比べて，周囲流体の大 気の密度が十分小さいため, 付加質量による $m$ 一の影 響妒無視できるものと考えられる，バネ定数 $k$ につい ては, 計測に用いられる振幅 $500 \mathrm{~nm}$ 以内では一定と みなせることがわかっている(3). 粘性抵抗 $D$ の影響に ついては，振動状態にあるプローブ球の状態を考慮す ると式(2)によるモデル化では不十分であると考えら れ，本研究ではより現象を表した流体評価を行うため
に, プローブ球まわりの流体解析を行う.

\section{3. 流体䉽析シミュレータ}

3.1 数位計算法およぴ計算条件 プローブ球ま わりに展開した計算格子（格子点 $20 \times 40 \times 20 ） の 一$ 部を 図 3 に示す．図3では原点にプローブ球まわりの格子. を配しており，半径 $r$ 方向に格子が指数関数的に拡が っているのを表している．流体の数值計算法には非慣 性系における SMAC 法を用いた(4)．空間差分法につい てはコロケート格子を用いた 2 次精度中心差分，時間 発展については，対流項は 2 次精度アダムスーバッシ ユフォース法, 粘性項はクランクーニコルソン法を用 いた．内部(球側)境界条件は，物体表面として滑りな し条件，圧力勾配なしとした。一様流中の球に働く流 体抵抗解析では, 流入境界は流速 $U$ が一様に流入し, 流出境界では対流流出条件を適用した，圧力境界条件 としてはノイマン条件を用いた。 プローブ球振動時の 解析では，計算領域が十分広いものとして流入境界で は流速 0 とし，流出境界では対流流出条件を用いた。 ただし，流入・流出境界条件は球の振動方向に応じて 変化するようにした，圧力境界条件としてはノイマン 条件を適用した。

$3 \cdot 2$ シミュレ一タ妥当性の検証 レイノルズ数 が 1 より小さいとき，理論では一様流中における球に 働く流体抵抗は式(2)で表され，抵抗倸数は $c_{D}=24 / \mathrm{Re}$ となる. この式を用いて，シミュレータの妥当性を検 証する. 図 4 に $\mathrm{Re}=1.673 \times 10^{4}$ のときの流れ場を, 図 5 に一様流中の球における理論による流体抵抗と数值 解析による流体抵抗の比較を示す．流体は $x$ の正方向 に流れるものとしており，図 4(a)から流速が $x$ の正方 向に生じ，球との摩擦によって流速が変化しているこ とがわかる. 図 4(b)から球の前縁では圧力が高く, 後 縁では低くなっていることがわかる。これらの結果は 一般的な一様流中での流れ場の状態と一致している. 図 5 では理論值と大変良く一致しており，十分信頼性 の高いシミュレータであることがわかる.

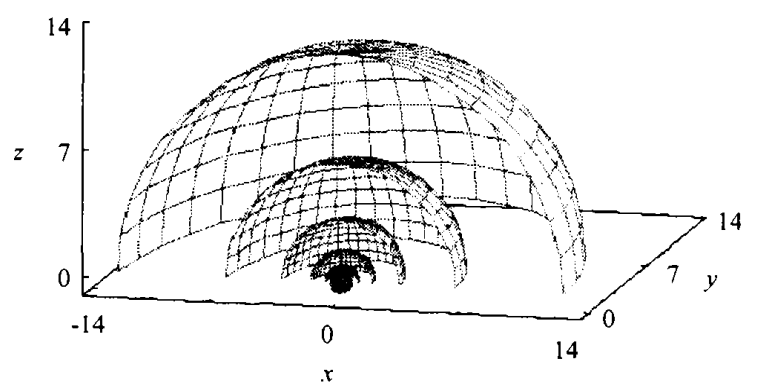

Fig.3 Numerical grid 


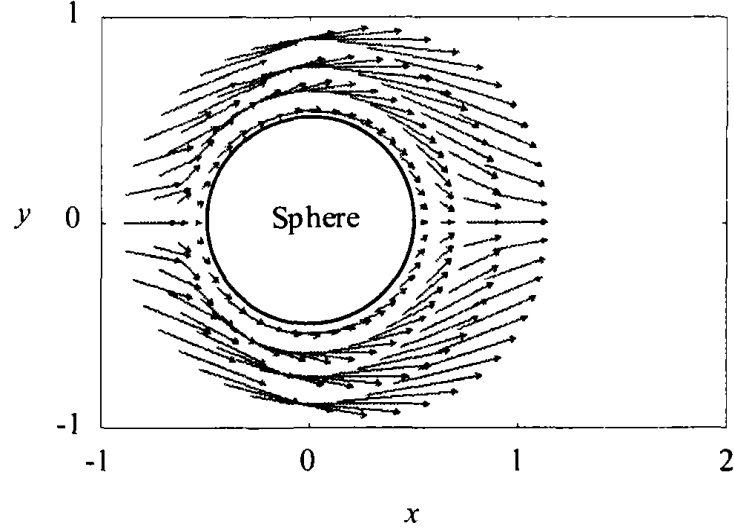

(a) Velocity field

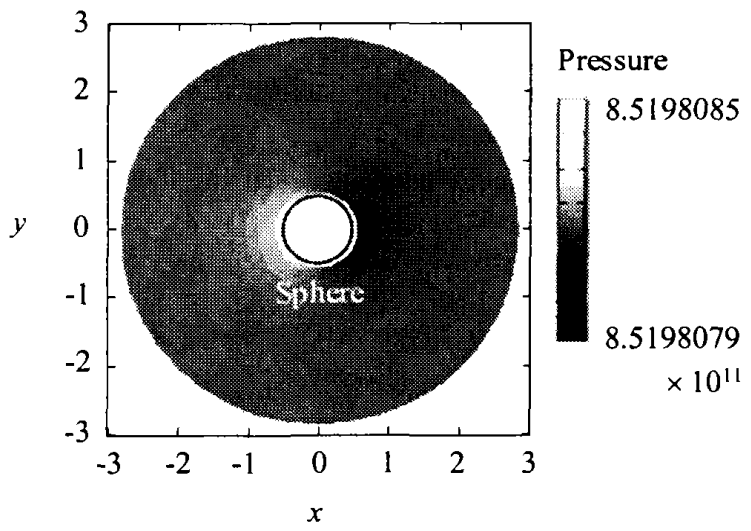

(b) Pressure field

Fig.4 Uniform stream around a sphere

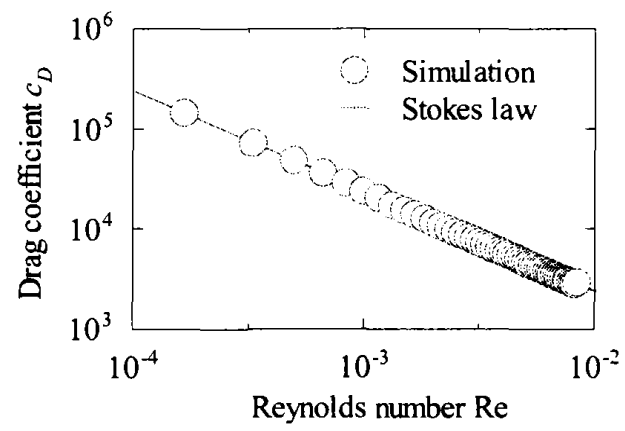

Fig.5 Drag coefficient in uniform stream

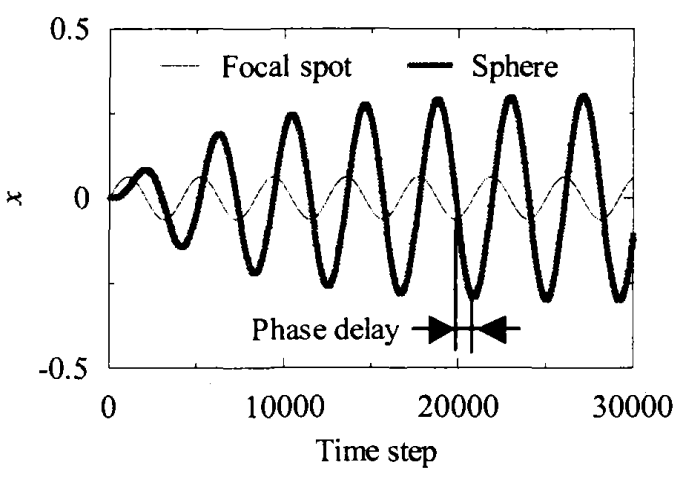

Fig.6 Displacement of oscillating focal spot and sphere
$3 \cdot 3$ 周波数応答解析 振動するプローブ球まわ りの流体解析を行った. 結果の一例として, プローブ 球の直径 $d=8[\mu \mathrm{m}]$, 周囲流体密度 $\rho=1.205\left[\mathrm{~kg} / \mathrm{m}^{3}\right]$, 粘 性係数 $\mu=1.81 \times 10^{-5}[\mathrm{~Pa} \cdot \mathrm{s}]$, バネ定数 $k=1.22 \times 10^{-4}$ $[\mathrm{N} / \mathrm{m}]$, 焦点振幅 $A=500[\mathrm{~nm}]$, 振動数 $f=2400[\mathrm{~Hz}]$ の ときの計算結果を図 6 に示す。図 6 は振動するレーザ スポットとプローブ球の振動方向での変位を表してい る.レーザスポットに追従して光放射圧で球が引き寄 せられ，共振することで振幅が大きくなり，周囲流体 の抵抗によって一定となっていることがわかる. 2400 $\mathrm{Hz}$ においては, 従来のストークス抵抗を用いて計算さ れる振幅比は5.91 となっていたが，流体解析の結果で は 4.84 となり，実験結果の值 5.07 に近づき，誤差が $17 \%$ から $4.5 \%$ 一と減少している. 実験結果との比較を 考えた場合, 従来の流体モデルを用いたフィッティン グよりも流体解析を用いたプローブ解析のほうがより 高精度に計算できていることがわかる。

\section{4. まとめと今後の方針}

SMAC 法を用いたプローブ球まわりの流体解析を 行った. $2400 \mathrm{~Hz}$ における実験結果とシミュレーショ ン結果を比較すると，従来の流体モデルでの值に比べ て, 振幅比, 位相遅れともに誤差 5\%以内と改善され, 大変精度の良い解析ができていることがわかった。こ のシミュレータに実験での周囲流体の条件を組み込む ことで，温度による周囲流体の密度や粘度変化といっ た実際の実験では計測が難しいパラメータについても 計測への流体影響を調べることができ，計測状態にお けるプローブ球に及ぼす影響をより詳細に解明するこ とができる.

\section{文献}

(1) Y. Takaya, K. Imai, S. Dejima and T. Miyoshi, Nano-Position Sensing Using Optically Motion-controlled Microprobe with PSD Based on Laser Trapping Technique, Annals of the CIRP, 54, 1 (2005), pp. 467-470.

(2) B.A. Nemet, Y. Shabtai, M.C. Golomb : Imaging microscopic viscosity with confocal scanning optical tweezers, Opt. Lett., vol.27, 4, 264(2002)

(3) T. Hariyama, Y. Takaya and T. Miyoshi, New Mass Measurement Method of Aerosol Particle Using Vibrating Probe Particle Controlled by Radiation Pressure, Proceeding of SPIE, Vol. 5993, 599308 (2005)

(4) S. Takeuchi, T. Yamazaki, T. Kajishima : Study of Solid-Fluid Interaction in Body-Fixed Non-Inertial Frame of Reference, J. Fluid Science and Technology, Vol. 1 , No. 1 pp.1-11 (2006) 